\title{
On the complexities and limits of market organisation
}

Richard R. Nelson

\section{Introduction}

The close of the twentieth century saw a virtual canonisation of markets as the best, indeed the only really effective, way to govern an economic system. The market organisation being canonised was simple and pure, along the lines of the standard textbook model in economics. For-profit firms are the vehicle of production and provision. Given what suppliers offer, free choice on the part of customers, who decide on the basis of their own knowledge and preferences where to spend their money, determines how much of what is bought by whom. Competition among firms assures that production is efficient and tailored to what users want.

This chapter's aim is not to gainsay the present conventional wisdom, but rather to civilise it, and make it more nuanced and subtle. Market organisation, broadly interpreted, certainly has proved an effective way to govern a wide range of economic activities, and for a number of these it is hard to think of an alternative that would do nearly as well.

However, here I want to argue, highlight, that modern societies are facing a number of challenging and contentious issues regarding how to organise and govern a variety of activities that employ a large and growing fraction of their resources, where simple market solutions do not seem a good answer. While for some of these for-profit firms free customer choice and competition can provide the core of a satisfactory governance structure, to make market governance work satisfactorily will require strong and fine-grained regulation, and perhaps a number of other supplementary non-market elements. And for a number of these activities it likely would be best to rely centrally on other basic organisational modes, with markets in an ancillary role.

This argument clearly flies in the face of conventional wisdom. Hasn't market organisation proved to be a general purpose way of governing economic activity? Haven't we learned that markets work best when there is minimal regulation or other interference from government? And hasn't negative experience with forms of economic organisation that repress markets and use other mechanisms ruled out serious consideration of nonmarket alternatives? 
I propose that the answer to each of these questions is more complicated than that implied by the way it is posed. To assess market organisation as a governing system, it is essential to widen the analytic context. By a governing system more generally I mean a system that does two roughly separable kinds of things. First, it defines the values and interests that are to count in the determination of what and how much is to be provided and distributed; the mechanism here usually can be characterised in terms of a process. Second, it involves an assignment of responsibility for provision and a system of incentives, controls and overview mechanisms for enforcing accountability. These two aspects of governing systems show up in political science as, on the one side, political process and policy making, and, on the other side, matters of administration and implementation. In economics the former clearly relates to the organisation of demand and the latter to the organisation of supply.

Market organisation clearly provides one kind of governance system, in the sense above, and one that is widely used. However, while the conventional wisdom seems to have it that market organisation is a relatively simple structure, in fact in many sectors generally thought of as market organised, the structure of demand and supply is highly complex, involving major nonmarket elements. Different sectors vary greatly in their mix of market and non-market elements. And even with this variegation and complexity, and hence the ability to tailor markets to particular circumstances, market organisation is not the principal governance mode we use for many activities and sectors. Indeed in a number of areas we actually try to fence out markets. These are facts in all capitalist countries, including the USA, despite a tendency to repress them.

Part of the difficulty many seem to have in seeing the complexity and the limits of markets as governing structures stems from the tendency to think of the economy as mainly concerned with producing and distributing things like peanut butter, automobiles, haircuts, telephone messages, and computers and computer services. However, a large share of an economy's resources are employed in activities that are central to the workings of our society, our political system and our culture. Some of these are conventionally thought of as outside the economic system - and appropriately outside.

A few examples will bring out the gist of the latter argument. Thus consider the care of young children, or crime prevention and criminal justice, to identify two areas where modern societies presently are facing some difficult problems regarding organisation and governance. Neither of these activities is governed largely through the market, at least as market organisation is generally conceived. While these cases are not what most people have in mind when they think of 'economic' activities, they certainly do employ considerable resources that could be used productively in other activities. Expenditures on the police and the courts get counted in the GNP statistics. So does much of child care outside of the family, and the purchased inputs used in family child care, and feminists have not been alone in arguing that housewives' services should be counted in GNP. And it surely is important that the 
quantity and quality of resources dedicated to these activities be appropriate to the task, and that these resources be effectively employed to serve the values at stake.

These examples are important in their own right, because they surely do present major problems of organisation and governance of activities employing substantial resources. But they are important also because they highlight the often neglected fact that the lines between 'economic' activities, and activities that generally might be thought of as social or political or cultural are blurred rather than sharp. An economy is not a sphere of activity that is separate from child raising, or from dealing with crime, or from supporting art or religion, or from political campaigning, for that matter. Rather, economics should be viewed as an aspect of any activity. From that point of view, it should be clear that the problem of economic organisation and governance is not simply about the production and distribution of commodities like peanut butter.

In any case, under standard circumstances, child care is presumed to be the province of the child's parents or extended family. At the same time, parents or those in a parental role are presumed to have an obligation to care adequately for their children: they are not seen as having a right to choose whether or not to provide that care, as they have the right to buy whichever kind of car they like or none at all. Preventing crime, and operating the criminal justice system more generally, traditionally are viewed as basic activities of government. In general, it is expected that individuals are to be treated as equals by the system, and that justice is 'not for sale'. In both of these areas there is considerable resistance to the idea of letting market values and mechanisms play a central role in governance.

But, of course, the market does play a role in these areas. Babysitters and nannies serve for pay. The demand for extra-family child care is large and growing and there are many for-profit as well as not-for-profit providers. Persons of wealth and social status are well known for getting a better break from the criminal justice system than those towards the bottom of the social order; they can, among other things, hire good lawyers. Also, there recently has been considerable use of for-profit contractors to run prisons, and many businesses and local communities hire their own private guards. While presently the role played by the market in these areas is relatively small, there is considerable debate about whether that role should be bigger or smaller.

Thus there is major dispute about how day-care providers should be regulated, for example about the qualifications of carers, and about acceptable ratios of carers to children. Day-care subsidy is another issue. The ability of the rich to buy favorable verdicts, and the frequent inability of the poor to obtain decent legal defense for serious crimes, has raised concerns about the quality of justice dispensed by the criminal justice system. In both child care and criminal justice markets are used, but no one is arguing that they should be unfettered. On the other hand, it is not clear just where or how to draw the lines. 
The governance of basic scientific research is another important area where, presently, the market plays a relatively modest role, but there is considerable debate about just what that role should be. The scientific community long has argued that it is a mistake to have conjectures regarding likely future practical application play a central role in the allocation of resources to basic research. Rather, the dominant criterion ought to be scientific promise, which the scientists themselves are in the best position to judge, and research findings ought to be published and open to anyone to test and use. For-profit companies are not much given to support research under those terms and groundrules. It long has been broadly accepted that funding basic research is an appropriate mission of government. By and large governments have provided funding for basic research under a regime of self-governance by scientists, with universities the principal locus of the activity.

However, while open publication and open access traditionally have been the norm in basic science, in recent years universities as well as business firms have begun to patent the results where they can, and to require that users take out licences and pay fees. And corporations now are important sources of support for basic research in certain fields, with their profiting from this activity tied to their ability to restrict access to results. There is a growing debate about whether or not public funds should go into fields of research that companies seem willing to support out of their own money, and regarding whether it is a plus or a minus that university research results increasingly are being patented. The debate can well be regarded as about the scope and nature of the role markets ought to play in governing the basic science enterprise.

Of course these three activities are not generally regarded as basically market governed. But consider some sectors that most people do think of as governed and organised through the market, for example pharmaceuticals or airline services. The products of both industries are highly regulated, as are some of the details of the operation of the firms in those industries. The R\&D of pharmaceutical companies draws heavily on publicly supported biomedical research, and a significant portion of the sales of pharmaceuticals is funded by various government programmes that support the provision of medical care. The airlines depend on investments in airports, which in many cases are publicly financed, and on a government-funded and -operated traffic control system. Or think of automobiles that run on public roads, under a specialised system of traffic law. Or agriculture.

As one reflects on these sectors and these activities, it becomes evident that the provision of supportive and regulatory bodies of law, and the necessary infrastructure, which are widely recognised as requisite tasks for government in order to make markets work decently well, are to a considerable degree sectorally specific. While often repressed in the current discussion, markets need non market structures in order to operate.

I propose that almost all activities in modern economies are governed through a mix of market and non-market mechanisms, with the relative 
importance of markets, the constraints put on their workings, and the strength and nature of non-market mechanisms varying from activity to activity, and from sector to sector. My focus in this chapter is on the debates about the mix.

Thus consider hospital services, another arena where the debate is intense. The hospital sector contains numbers of both public and non-profit units, as well as for-profit hospitals. Part of hospital revenues comes from private patients and private insurance. Part comes from public programmes that support the care of persons in certain categories. Hospitals are subject to a number of different forms of regulation. Physicians, as a profession, play a major role in determining what is done. In recent years, managed-care organisations and insurance companies also have played major roles in the hospital governance structure. There is often bitter debate about the relative power that these different parties and interests should play in the governing structure, as well as about the role of public finance in supporting the system.

Or, consider some of the issues surrounding the governance of the Internet. Should the content of the Internet be regulated, and if so in what ways and by whom? Should the Government require that the Internet be made available on favorable terms to schools, and if so who should pay for it?

Other areas of dispute involve markets for things some people believe should not be bought and sold, or in some cases should not be available at all. Reflect on the controversy about the emerging market for kidneys and ova, or about the decriminalisation of prostitution and drugs.

This already is a lengthy and diverse list of areas where the appropriate role of market and non-market modes of governance is under dispute. But let me stress their common properties. They all involve a particular class of goods or services that do or arguably should show up in the GNP accounts, because they employ scant resources to meet particular kinds of human needs. And they all involve disputes about the appropriate structure of governance, that is about the values and interests that are to count in the determination of what and how much should be provided and distributed, and about who is to do the work under what regime of incentives and controls.

While there is overlap, I want to differentiate these kinds of economic governance disputes from those that are central to macroeconomic policy; the issues I am considering here are microeconomic. In some cases the issues I am focusing on here are intertwined with policies concerned with income distribution. However my focus is on disputes about the governance of particular activities or sectors, with the question of who pays sometimes figuring as part of the dispute, but the central issue is not income transfers per se.

Despite these commonalities, the issues I touched on above still would appear to be very heterogeneous, and appearances here are not deceiving. An important point I want to get in view is that the particular key issues of governance, and the arguments about what markets can and cannot do well, differ from activity to activity, and hence from sector to sector. However, a principal purpose of this essay is to try to make some order of this apparent 
jumble of issues. Later in this chapter I develop a relatively small collection of analytic categories which, I propose, encompasses a large share of the issues at stake. But first I need to set the stage.

I begin by trying to place the current broad debate, which starts from a degree of faith in the efficacy of markets that is almost unprecedented, in some historical perspective. Then, in the following section, I consider the various virtues that purportedly characterise market organisation and elevate it over other kinds of governance structures, and raise some questions about those arguments. The fourth section is concerned with 'market failure' theory, and other broad theories that point towards the desirability of a mixed economy.

In the penultimate section I return to the issues referred to above, and try to bring order to them by proposing a set of categories into which, I argue, most of them fit. Finally, a reprise.

\section{The past as prologue}

The presumption and the fact that markets play a pervasive role in the governance and organisation of economic activity are relatively recent phenomena. A significant expansion in the role of markets occurred first in Great Britain around the beginning of the eighteenth century, and later spread to continental Europe, and the United States, still later to Japan, and more recently to large portions of the world. Of course certain kinds of markets have existed from virtually the dawn of history, but until recently were central in only a small portion of human activity. It is the pervasiveness of markets and of the system that came to be called capitalism that are relatively new on the historical time scale.

With the spread of markets - of production that was largely for sale on markets, and of a context where either receipts from sales or wages garnered on labour markets largely determined the access of an individual or family to goods and services - a sphere of economic activity began to emerge in its own right, as a system that was distinct from the broader society and polity. Thus Adam Smith's (1776) The Wealth of Nations is about a market economy, influenced profoundly to be sure by the culture and governance of the nation containing it, but as an object in its own right, and with its own basic rules of operation. That book could not have been written a century earlier. And today, of course, the standard economics textbooks draw a picture of an economy that is quite separate from the rest of human activity.

From the time capitalism began to take on recognisable form, and students of its operation began to write about it (with time these analysts came to be called 'economists'), the system has had its proponents and its opponents. The balance of opinion about capitalism has swung back and forth over the years, and at any time has varied from country to country.

While the British 'classical school' often is thought of as comprising strong proponents of markets, as unencumbered as possible, and extended to as 
wide a range of human activity as possible, in fact that is not quite accurate. Adam Smith's enthusiasm for markets was nuanced, and he clearly saw a downside. John Stuart Mill did not like certain aspects he saw of the rising capitalism of mid nineteenth-century England (1961). The USA today is regarded as the locus of almost unwashed enthusiasm for unfettered markets. However, Alexander Hamilton, in his famous Report on Manufactures (1791), argued that protection and subsidy were needed if American industry were to survive and prosper. Many of the founders of the American Economic Association (towards the end of the nineteenth century) were much concerned about what they saw as the excesses of market capitalism, and with devising policies to tame it.

Outside of the UK and the USA, and the cultures they have strongly influenced, the enthusiasm traditionally has been even more muted, and the climate of opinion sometimes downright hostile. Indeed the socialist economic tradition was to a considerable extent basically a negative reaction to market capitalism. That tradition constituted a very roomy tent. On the one side one can find the British Fabians who did not want to abolish markets (at least not in the short run), but rather to regulate them in the public interest, and to supplement markets with a variety of other institutions to deal with the inequities they saw as inevitable in raw capitalism. On the other side stand diverse scholars who were strongly hostile to the market system and who proposed to completely replace it with something else; here one finds socialists as diverse as Robert Owen and Karl Marx.

Marx of course saw capitalism as a system of power. For him, political and economic power were intertwined. It is no coincidence that, until recently, nationalisation of heavy industry and, more generally, of the organisations that provided the basic infrastructure for economic life was at the top of the agenda for socialist parties, after they were able to attain and hold political power.

With all the enthusiasm today for market capitalism of a relatively extensive and unrestricted sort, it is easy to forget that half a century ago some of the most distinguished scholars were predicting capitalism's demise. Between 1940 and 1950 Joseph Schumpeter published his classic Capitalism, Socialism, and Democracy, and Karl Polanyi his The Great Transformation. Both saw capitalism as a system whose time had passed, the former with regret and the latter with relief. The reasons for these predictions are, interestingly, somewhat different.

For Schumpeter, the reasons were twofold. First of all, he argued that the principal economic merit of capitalism had been the rapid and radical innovation the system spurred and supported, which was the basic factor behind the great improvements in living standards that had occurred under capitalism. However, he believed that, as a result of the advance of science, rapid industrial innovation no longer required the hurly burly of competition, but could proceed in a planned and orderly way. Thus capitalist economic organisation no longer was needed for economic progress. At the same time the professional managers of industry and the scientists in R\&D had little 
zeal for keeping competitive capitalism going as a system: their careers would be more secure and as comfortable under a different regime. This left the defenders of capitalism even more vulnerable to the attacks of intellectuals who saw many vices and few virtues in the system.

For Polanyi, market capitalism had been a disaster for the working classes and, while since the late nineteenth-century wages had risen somewhat for those who had jobs, the great depression showed that capitalism remained a pernicious system. More, (and here Polanyi's line is similar to that of Schumpeter), the depression had weakened the support of the middle classes, and even business, for the system, and was leading them to look to taming it or transforming it so that it was less brutal.

Both authors saw the economic system of market capitalism as profoundly influencing the nature of broader society and politics. Schumpeter saw the effects as largely positive, as encouraging individual creativity, freedom and independence. Indeed, he associated the institutions of modern science with capitalism, and argued that liberal democracy was a fellow traveller, a position very close to that of F. A. Hayek. For these reasons he viewed with regret what he saw as the inevitable decline of capitalism.

Polanyi's great book, on the other hand, put forth the argument that the encroachment of markets on everyday life and, in particular, the commodification of labour and land had destroyed the co-operative and communal aspects he saw as essential to a healthy civil society. He saw the defence of capitalism against the pressures of working-class interests as a fundamental aspect of political regimes under capitalism, so that a true democracy was very difficult to achieve so long as capitalism held sway. On the other hand, part of his argument as to why capitalism was dissolving involved precisely the extension of democracy despite the resistance of capitalism's defenders.

Neither author displayed any enthusiasm for the Soviet system that was taking shape at the time. But both clearly forecasted an economic system that involved far less competition among firms, and far more co-ordination, much more government regulation of firms and particularly the labour market, greater protection of the basic living standards of workers and more planning than did the system that had come to be called capitalism.

It is apparent that the strong performance after the Second World War of the European and American economies surprised many people, and changed attitudes. Unemployment was low. The economic growth rate was high and the lion's share of the population experienced rising living standards.

It was widely recognised that post-war capitalism was structurally different from that of pre-war days in a number of dimensions. The roles of government had expanded significantly. Public spending on education, particularly higher education, had increased greatly, and so had government support of R\&D. There were major public investments in roads and other infrastructure. Unemployment insurance now was widespread and in many countries quite generous, as was social security. Many countries expanded the scope of national health insurance, or instituted new programmes. Both 
France and the United Kingdom established an apparatus for centralised economic planning, or at least indicative planning. The United States saw the passing of a full employment act and the establishment of a President's Council of Economic Advisors.

How much these systems changes had to do with the strong performance of the economies in the quarter century after the Second World War still is an arguable matter. However, it is clear that many of the forecasts of Schumpeter and Polanyi regarding systems change had come to pass.

One could ask whether the new system still was market capitalism. C. A. R. Crosland asked that question in his 1956 opus The Future of Socialism, and answered that the system was very different from what it had been, and that it contained a number of elements long advocated by socialists, but still was not socialism. In Beyond the Welfare State (1960), Gunnar Myrdal also stressed the great change that had occurred and in effect took the position, whatever it might be called, that most of the problems of the old capitalism were resolved by the new system. Andrew Schonfield, in his Modern Capitalism written in 1965, took essentially the same position.

American scholars put forth a distinctively pragmatic perspective on these developments. Robert Dahl and Charles E. Lindblom in their great Politics, Economics, and Welfare (1953) proposed that the tasks of modern economies were complex and varied, and that different forms of governance and organisation are appropriate to different ones. The book basically layed out the wide range of different principles the United States used to organise different kinds of activities. Daniel Bell's The End of Ideology (1960) argued that in the United States, at least, no one was still arguing about the pluses and minuses of capitalism; rather, the discussion was about how to make it work well.

In the United States economists increasingly used the term 'mixed economy' and, when talking among themselves, 'the neoclassical synthesis'. The basic themes were well articulated in the 1960 report of the new Kennedy administration's Council of Economic Advisors, which contained a number of the country's best-known and most respected economists. Centerpiece in the formulation was the Government's role in managing the macro aspects of the economy through fiscal and monetary policy; several years later the Republican President Richard Nixon would say 'We are all Keynesians' (see US Government, 1960, 1967). Market organisation was assumed to be the basic way of governing and managing industry, broadly defined. However, the theory of 'market failures', to use a term I will unpack later, was very much part of the neoclassical synthesis. The provision of public goods, like national security and scientific knowledge, required public support and in some cases public undertaking. Externalities required regulation or a regime of taxes and subsidies. Anti-trust policies needed to be pursued and natural monopolies needed to be regulated. And the Government needed to proceed actively to assure that the workings of the economic system did not generate unrelieved poverty. There were only a few years between the Kennedy administration's first economic report and the 'war on poverty'. 
These changes in economic policy or, more broadly, changes in the view of what capitalism was and what was needed to make it effective did not go unchallenged. By the middle or late 1970s there was considerable advocacy for rolling back many of the changes or, at least, blocking further moves in those directions. Mark Blyth has proposed, in his 'Great Transformations', (2000), that there may be a natural cycle regarding popular opinion on the appropriate level and kind of government regulation, and involvement more generally, in capitalism, a cycle that involves both policies and ideologies, with overshoot of the former leading to switches in the latter.

However, it is fair to say that the seachange in ideology on these matters reflected in the rhetoric and the policies of the Margaret Thatcher and Ronald Reagan administrations caught many people by surprise. The sharp changes undoubtedly had many causes. One was the deterioration of the performance of the American and European economies that set in during the early 1970s. This was associated with a continuing rise in government spending as a fraction of GNP, and many argued that this, together with increased government regulation, was a root cause of the economic problems. And clearly the collapse of the Soviet economy bolstered the advocates of market capitalism - of a relatively simple and raw variety.

The 1980s and 1990s saw a dramatic change in intellectual writings about capitalism. Daniel Yergin and Joseph Stanislaw wrote about how the marketplace had won over government in the battle for The Commanding Heights, and saw the outcome as a victory for the right cause, expressing few qualms that the issues might be more complex than the ideological arguments of the victors. Francis Fukuyama proclaimed The End of History and the Last Man (1992), as a final victory for market capitalism (along with liberal democracy).

And yet, for all the attempts to roll back the reforms of the early post-war era and to return to a leaner and more basic capitalism, the actual systems remain extraordinarily complex and variegated. The welfare state has become a recognised part of modern capitalism, a mistaken idea in the minds of some, a necessary complement to the industrial side of modern capitalism to others, but certainly an arena of continuing policy argument. With growing recognition of the central role of technological advance in economic growth, and of science to technological advance, the old industrial policy debates have taken on new form, but the debates continue. The waves of deregulation and privatisation that marked the 1980s have not ended the debate about whether for-profit firms can be trusted in contexts where competition is problematic or the good or service being provided is crucial to the well-being of the society or polity.

In my view, however, while for the most part the contemporary discussion of issues of macroeconomic policy has broken from the ideological narrowness of the 1970s and 1980s, that is less true regarding problems of economic organisation. Too much of the current discussion of how to govern economic activity still proceeds within an intellectual frame that sees modern capitalism, 
and in particular market organisation of economic activity, as far simpler than it actually is. I think it very important to get the complexity and variegation of market organisation, and its limits, more clearly in view.

\section{The case for market organisation: the perspective from economics}

I have noted that, while recently there is fraying around the edges, over the last twenty years belief in the efficacy of markets has been unusually wide and deep by historical standards. Non-economists seem under the impression that economists have built a theoretically rigorous and empirically well-supported case for market organisation. In this section I argue that, in fact, the most commonly cited theoretical argument can support little weight, the empirical case is rough and ready, and the persuasive part of the argument is pragmatic and qualitative rather than rigorous and quantitative. And, in my view at least, the arguments for market organisation that are most compelling are quite different from those contained in the standard textbook formulation.

Since at least the days of Adam Smith, the Anglo Saxon tradition of economic analysis has touted the virtues of the 'hidden hand' - profit-oriented suppliers striving for customer purchasers on a competitive market. For the most part Smith's argument was qualitative, and supported by a set of empirical cases drawn from his own experiences and those of others. Also, in the present context, it is important to remember that Smith was making his case for market organisation partly as argument against a particular alternative - mercantilism.

Modern economics purports to tighten up the logic of the argument. The theoretical case made for market organisation in contemporary economics textbooks and treatises compares the performance of a stylised model market economy against a theoretical norm of Pareto optimality. Pareto optimality is a sophisticated notion of maximal economic efficiency. If the performance of an economy is Pareto optimal, it is getting the maximal value of output from the resources and technologies available, given the distribution of purchasing power. (This is not the standard definition of Pareto optimality, but it is nearly equivalent.) The textbook argument concludes that, given a package of assumptions, a competitive market economy meets that norm. However, while Nobel prizes have been awarded to economists for developing this theory, I would argue that it is a non-starter as a case for real life market organisation for several reasons.

The primary one, of course, is that the theoretical model of a market economy that satisfies the criterion of Pareto optimality is very far away from actual market organisation. Strangely, the implications of this for the whole broad argument have tended to be underplayed.

Even if one stays close to that theoretical formulation, almost all analysts would admit the presence of a variety of 'market failures', a topic I take up in the next section. Once these are taken into the model, the theoretical market economy does not achieve Pareto optimality. And from there the whole theoretical strategy of the case for markets unravels. 
It unravels because, unlike Smith's discussion of the virtues of the hidden hand, which did involve an explicit comparison, the contemporary theoretical textbook argument does not compare the performance of a (highly abstracted) market-organised economy with the theoretical performance of another (highly abstracted) kind of economic system. In particular, the argument is not that another kind of economic system could not also achieve Pareto optimality. Of course, if market organisation does as well as is theoretically possible, there is no particular reason to consider an alternative. However, once the optimality argument falls away, there would seem to be no way to avoid comparing how market organisation does against alternative structures, even though this may be very hard to do.

The task is made especially difficult by the fact, which I have been stressing, that modern market capitalism (or any plausible alternative system) is very complex and variegated. The argument I am developing clearly is that it is exactly this flexibility which enables market organisation to work tolerably well in a wide variety of contexts. But then these factors absolutely need to be taken into account in any analysis which compares market capitalism against alternatives, or against some kind of an absolute scale.

There is also the question of the kind of performance attributes one should use to evaluate market organisation and its alternatives. Much of modern economic analysis is focused on economic efficiency - the value of the output (given the distribution of purchasing power) that an economy is able to achieve with given resources and technologies. While real life market economies certainly do not achieve Pareto optimality, most economists would argue that market organisation and competition often do seem to generate results that are moderately efficient. There are strong incentives for firms to produce goods and services that customers want, or can be persuaded they want, and to produce them at as low financial cost as is possible. There is a 'dynamic' version of, or supplement to, this efficiency argument. Under many circumstances competitive market-organised economic sectors seem to respond relatively quickly to changes in customer demands, input supply conditions and technological opportunities. To the extent that producing what customers value is treated as a plus, and so long as factor prices roughly measure opportunity costs, there is a strong pragmatic case for market capitalism on economic efficiency grounds, broadly defined, at least in certain domains of activity.

But the question is 'compared with what?' and 'in what context?' It is interesting that in wartime, and almost without protest, capitalist economies have adopted centrally co-ordinated mechanisms of resource allocation, procurement and rationing. The rationale has been that such economic organisation was essential if production was to be allocated to the highest priority needs, and conducted efficiently. And the experience with wartime planning sometimes has led some analysts to propose that a number of the mechanisms used then would vastly increase economic efficiency during peacetime. 
On the other hand, most knowledgeable analysts have argued against that position, strongly. It is one thing to marshall an economy to concentrate on a central set of demands over a short period of time. It is something else again to have an economy behave reasonably efficiently and responsively in a context of varied and changing demands, supply conditions and technological opportunities, over a long time period. The experience with central planning in the formerly communist countries, particularly after the era when building up standard economic infrastructure sufficed as a central goal, bears out this argument.

However, I would propose that the argument behind the scenes here is much more complex, and in fact different, from the standard textbook argument that profit maximising behaviour of firms in competitive market contexts yields economically efficient results. It hinges on the multiplicity and diversity of wants, resources and technologies in modern economies that, experience shows, defy the information processing and resource allocating capabilities of centrally planned and controlled systems, and also presumes that the chances of appropriate responses to changed conditions are enhanced when there are a number of competitive actors who can respond, again a proposition consistent with experience. Many people find that case for market organisation compelling, and in accord with the evidence both about capitalist economies and about the old planned ones. That case, however, has nothing to do with a theoretical argument about the Pareto optimality of a stylised market economy, but rather rests on an empirically well-founded belief that, in a complex and changing environment, decentralised market systems work better than highly centralised ones.

Many observers have proposed that it is in dynamic long-run performance, rather than in short-run efficiency, that market capitalism reveals its greatest strength. As Marx and Schumpeter have stressed, capitalism has been a remarkably powerful engine of economic progress. And here too one can make a rather explicit comparison. Indeed a good case can be made that a central reason for the collapse of the old communist economies was their inability to keep up with and take advantage of the rapid technological progress that was going on in market economies.

But, again, the characteristics and capabilities of market organisation that contribute to technological progress are very different from those that relate to static efficiency, and those of the normative textbook model. Indeed Schumpeter made a great deal of those differences. The capitalism of his Capitalism, Socialism, and Democracy was an effective engine of progress because competition spurred innovation. This theory places high value on pluralism and multiple rival sources of invention and innovation. However, under this view of what socially valuable competition was all about, the presence of large firms, with R\&D laboratories as well as some market power, was welcomed, despite the fact that such a market structure diverged from the purely competitive one associated with the static theorem about Pareto optimality. More, the very process of competitive innovation was itself a 
source of efficiency differences across firms which, from a static perspective, could be viewed as inefficiency in the system as a whole.

Earlier I noted that Schumpeter argued that as science had become more powerful, the unruly and inefficient competition of capitalist systems would no longer be needed for industrial innovation, which increasingly could be planned. History has shown him to be very wrong on that point. However, I would argue that the strong performance of market capitalist economies on this front probably has as much to do with features of modern capitalist economies which are absent from the economists' standard model, as for example public support of university research, as with those that are included in that model.

In concluding this section it is relevant to recall that not only was Schumpeter's appreciation of the economic power of capitalism different from that which was being articulated in the then-rising neoclassical economics (although not inconsistent with views of earlier economists like Smith). Schumpeter also admired the cultural, and the political, values and structures that he saw induced and supported by capitalist economic organisation. On the other hand, Polanyi detested what he thought capitalism did to people, values and politics. It is apparent that the arguments for and against market organisation, and capitalism more generally, are concerned with issues at some distance from evaluations of performance on strictly economic grounds, whatever the latter might mean. Both Schumpeter and Polanyi believed that capitalism could not survive politically, at least in its raw form, because of widespread distaste for its social consequences. Clearly many of the post Second World War reforms were attempts to mitigate those consequences.

Which brings the discussion back to the question 'What is modern capitalism?'. And what are the alternatives? Years ago it was reasonable to compare capitalism and various aspects of its performance against communist systems, but this is no longer a relevant comparison. Today no one is seriously proposing an economic system that does not make extensive use of markets. The real issues today relate to the mix of markets with other forms, in different economic activities and sectors. And here, while a number of people have in effect put forward the proposition 'The more of market and the less of other things the better', I know of no convincing argument to support that proposition.

\section{The positive case for a mixed economy}

Why is there so much in the way of non-market elements in modern capitalist economies? Contemporary advocates of a purer form of capitalism argue that it is all a mistake or partially the result of a conspiracy. My argument, of course, is that these non-market elements are essential to make the economic system work tolerably well, and to ensure the support of its basic structure under democratic institutions.

In this section I consider three bodies of theorising that provide arguments for a mixed economy. By far the best known is the economists' theory of 
'market failure', in which limitations of market organisation provide reason for market supplementation or the substitution in some cases of non-market forms. Partly because it is so well known, and partly because its categories and conceptions are developed and criticised in the this section following, here I can be brief about this body of theory.

Rather, my focus is on two other bodies of theorising. One is concerned with the essential roles of the state. The orientation here is not to the need for the state or other non-market forms because markets occasionally fail, but to functions that naturally fall to government, including those that government has to perform to enable other institutions to operate tolerably well. The other body of theorising takes human society as basic, and is oriented to the rights and obligations of individuals within society. Market organisation can either help support this more fundamental structure or can be damaging to it; within this framework the question of where markets should and should not be admitted depends on how and where markets impinge on basic social structure.

\section{Market failure theory}

Without question, most of the high-level argument about how to use market organisation effectively, where market organisation needs to be supplemented by other mechanisms, and where market organisation simply works poorly, is conducted using the economists' 'market failure' language. The standard categories of market failure - public goods, externalities, monopoly problems, information impactedness, and (in some treatments) income distribution problems - serve to structure and constrain much of the policy discourse. Indeed since the 1960s, when this theory became solidly incorporated in mainline economics, almost every new president's Council of Economic Advisors has walked through basically this list in its maiden annual report to Congress and the American people, as part of its articulation of the economic policies its administration was proposing to implement.

Here I want to highlight several things about standard market failure theory that I develop in the next section. In the first place, market failure almost always is a matter of degree, not of kind. Or, from another point of view, market failure is ubiquitous: markets always 'fail' to some extent, in one way or another. This of course is an issue I flagged in the preceding section, where I also pointed out that an implication was that an explicit evaluation of organisational alternatives was needed before one could assess the implications regarding appropriate organisational form. Unfortunately, given the present state of our knowledge, economists and social scientists do not have the capability to engage in confident analysis of the likely performance of a wide range of organisational alternatives, or even to analyse the complex mixed market structures that have evolved in many sectors. But, on the other hand, a number of sophisticated advocates of market organisation have argued that the standard theory of market organisation, because it greatly oversimplifies what actually goes on in real markets, far exaggerates the 
extent to which markets 'fail', because in fact particular markets have evolved various procedures and structures that deal with problems which the simpler theoretical structure would see as sources of market failure. It should be clear that I have considerable sympathy for this point of view. By presenting a drastically oversimplified model of market organisation, standard economic theory blinds itself to the remarkable versatility of market organisation, broadly defined. Conventional market failure theory takes attention away from the remarkable diversity of markets.

However, by the way it is formulated, market failure theory carries a heavy normative load to the effect that markets always are to be preferred to other basic forms of organisation and governance, unless they are basically flawed in some sense. Thus the only reason why government should provide for national security and protect citizens from crime is that markets cannot do those jobs well. Parents need to take care of children because of market failure.

\section{The functions of the state}

As one reflects on it, the argument that we need government simply because markets sometimes 'fail' seems rather strange, or at least incomplete. Cannot one make a positive case for government (or families for that matter), as a form that is appropriate, even needed, in its own right?

And of course there is an ancient body of theorising that puts forward a positive case for government. In much of its early incarnation, and some of its more recent, the state is viewed as the structure through which an organic community governs itself, and values are defined at the level of the community. Reflect on Plato's discussion in The Republic (1961), or Hegel's discussion, where the good state is defined in terms of justice and morality and the quality of persons (1967). Under this conception of the relationships between a collection of individuals and families and their state, the good of the whole is by no means adequately judged in terms of the sum of the 'happiness' of the individuals that comprise it. This notion is very much alive in discussions about matters like the quality of justice in a society, or the aims of foreign policy. Arguments about how these activities should be governed involve beliefs about appropriate collective values, or the values of the collective, that transcend those of particular individuals. Under this theory, in these areas at least the state is the natural vehicle of governance, rather than something that is justified on grounds of market failure. In these areas the state may choose to use markets, but the purpose being served is a public purpose, and the responsibility for furthering it ultimately is a state responsibility.

It is important to keep this point of view in mind, because it plays a major role in a number of areas of contemporary dispute about governance. As I will propose shortly, in many of these areas the collective value argued to be at stake involves basic community and human rights, which I want to treat as a distinct body of theorising in its own right. Thus in the remainder of this subsection, I focus on another strand of political philosophy, particularly Anglo-American political philosophy. 
From at least the times of Hobbes and Locke, theories about the importance of the state have involved, centrally, the proposition that a strong state is necessary for individuals to lead secure, decent and productive lives. Originally this body of theorising had little to do with economics, much less with the role of the state in market economies. Thus Hobbes's case for a strong state to establish and enforce a clear body of law was posed in terms of the need to avoid the 'war of every man against every man'. While this case involved security of property, that was not its central orientation. With Locke, the orientation is more towards security of property, but his great writings were before capitalism emerged as a recognisable economic system.

In The Wealth of Nations, Smith built on these ideas and specialised them to the market economy he saw as working in Great Britain. He ascribed the backwardness of countries like eighteenth-century China largely to the vulnerability of possessions to thieves or simply to being confiscated by those in power. To have an incentive to produce for the market, craftsmen needed to be confident that they would reap what they sowed. Trade required contracts in which the traders had confidence, and that required a body of supporting law and a tradition of law enforcement that would not simply obey the interests of the wealthy and powerful. I call this required political and legal structure 'needed infrastructure'.

In Smith's day, not much physical infrastructure was necessary to make markets work. There were roads and canals, which government could either build and maintain itself or franchise to private parties. While Smith included in his functions of government the support of education, his case assigned at least as much importance to education as a factor supporting civil society as the role he perceived formal education to play in the operation of the economic system more narrowly defined.

As technology advanced and economic systems became more complex, the physical and legal infrastructure needed for the effective operation of market economies became more complex and variegated. Establishing the telegraph and railroad systems required government action, if not necessarily government finance and operation. With the emergence of the organic chemical product industry and the industrial research laboratory in the last part of the nineteenth century, effective patent law became important as a precondition to profitable $R \& D$ in a number of industries. Education became more important economically, and in industries like those producing fine chemical products firms needed scientists with a doctoral level of expertise. Earlier I briefly discussed the legal and physical infrastructure, provided by government, that support the modern airline, pharmaceuticals and automobile industries.

Now the question of what infrastructure has to be provided for markets to work well, and what it is that markets themselves can be expected to provide, often is not easily answered. However, 'needed infrastructure' provides a point of view on some of the current argument about the role of non-market structures in market-oriented economies that is different, I propose, from the 
modern theory of economists about conditions of market failure. Thus consider activities like maintaining a system of contract law, building and maintaining a road system, and supporting the development of basic scientific knowledge. These activities can be viewed as public goods, in the sense of market failure theory, with the market failure stemming from the fact that their benefits are collective rather than individual, and hence that to profit firms would have great difficulty collecting for their provision on a conventional market. Or they can be considered as 'needed infrastructure', the provision of which is a function of governments. However, while the former theory sees the reason for governmental provision or overview and control in the inability of markets to do an adequate job, the latter sees provision of such goods and services as a central responsibility of government, even if they could be provided through market mechanisms. And where market mechanisms in fact are used as part of the machinery for provision, the latter perspective sees government as still responsible for overseeing the operation, at least to some degree.

Support of primary and secondary education is an interesting case in point. While many laypersons clearly consider education to provide a public good and to be a responsibility of government, economists have trouble squaring the former notion with their technical definition of a public good, and more generally tend to struggle with the reason why government should be responsible for education, in view of the large benefits to those who get the education. While the notion that education yields externalities helps along their analysis, that perspective would seem to justify some subsidy to education but hardly the major governmental responsibility in the field that is the case in most countries. It would seem that non-economists tend to place education in the 'infrastructure' category, and hence have no trouble with the notion that government is responsible for supporting it, and for governing and monitoring education at least broadly, although some would argue that private schools ought to play a significant role in provision.

\section{Social cohesion and human rights}

Education also is an example of the kind of goods and services that, under the third body of theorising identified here, is considered a basic human right, or right of citizenship, and thus which ought to be available to all, independently of their money income or wealth or social status. Thus all citizens ought to have the right to vote, to trial by jury, and to legal aid if they cannot afford it on their own. Most societies recognise a similar right to an education, up to some level at least. Access to these basics of citizenship are seen as something that should not be rationed through markets, and for which government has a fundamental responsibility.

The core arguments of modern welfare state theorists combine these venerable arguments with a set of policies designed to shield individuals, and society as a whole, from what they see as the ravages of raw capitalism. Thus a set of economic rights have been added to the older political rights. This 
decoupling of access to a considerable range of goods and services from normal market process is the hallmark of the modern welfare state idea.

Above I noted the overlap between theories of the state that see collective values as transcending individual values, and modern welfare state theories. There is a difference, however, in that while the former tends to see certain values as associated with the institution of the state per se, the latter sees collective values as based on individual values, plus a notion of a shared uncertain environment, plus extended empathy.

In any case, under this theory the governance argument is not about particular market failures but about the basic rights of humans in society, which is not the same thing. This latter point of view of course poses the challenging question of how one draws up the list of things that should be available to all, or rather how one makes the cut off. The rights to vote, to equal protection under the law and to a basic education are on everyone's list. Unemployment and disability insurance, and at least a minimal level of retirement income, have been provided to all citizens in all high-income countries, and are not now controversial. But should medical care be on that list, and if so what level of care? Adequate extra family child care? It is not clear how we are to go about answering these questions. But it is clear that the answers are not readily posed in terms of resolutions of market failures.

It also is clear that, from this perspective, the notion of a society as simply a collection of people and families who have their own independent wants and purposes misunderstands what human societies are. 'Solidarity' is a word often used by advocates of this position. From another (sometimes closely related) tradition we all are our brothers' keepers.

From that point of view, many of the market failure concepts of traditional modern economics take on a very different light. Most importantly, in my view, there is a major difference in how one conceptualises public goods. As a salient example, one can ask whether the care and well-being of children create a public good. From the standard perspective in economics, the answer certainly is no. From a more communal position, every child is one of our children. The well-being of every child is a concern of all of us. The general welfare of children in our society is something we all should be concerned about. From this point of view, child welfare certainly is a public good. More generally, from this perspective the governance and administration of economic activity need to be arranged so as to support a just and equitable society, which is the most public of public goods.

\section{A synthetic perspective}

In this section I try to bring together the three theoretical strands just discussed, to develop an analytic mapping of the kinds of activities and sectors where the appropriate role of the market and other governing structures is a matter of controversy. In developing my mapping of issues, I take two things for granted. 
First, there are numerous activities and sectors where governance through market organisation is generally regarded as unproblematical. This is not to deny that there is any regulatory structure involved or, in some cases, supplementary non-market activity. However, no one seems to be suggesting that markets are an inappropriate basic governing mode, or arguing for a radically different governing structure. Textile production, automobile manufacture, restaurants, haircuts, house building, all would seem good examples. The list is long and broad.

But, second, I also take for granted that there are many activities for which markets are generally not regarded as the appropriate basic governing structure, and in fact we use alternatives. Some market activity may be involved, but in an ancillary way, and there is widespread agreement that if market principles and mechanisms became dominant, there would be a problem. The two examples I used at the start of this essay seem apt: child care by the family, and police and criminal justice more broadly. I suspect few would argue that governments do not have a basic responsibility for assuring the adequacy of national security or the regional water supply. Organised religion and little league baseball are activities where I suspect many people would reject a central role either by government or by for-profit firms. Most would agree that elections and particular pieces of legislation ought not to be for sale.

The categories I develop below are strongly influenced by the standard list in the economists' market failure theory. However, recognition of the central limitations of that theory, and the integration into the discussion of the other two strands of analysis that I introduced in the preceding section, yield (I believe) a richer characterisation of the reasons why and the arenas wherein many people are arguing that simple market structures need to be supplemented by ancillary mechanisms in order to be acceptable, or even fenced out. I focus particularly on areas and issues that seem to mark terrain that is strongly contested.

\section{Latent public goods}

Economists use the public good concept to flag a class of goods and services where the benefits are collective and communal rather than individual and private. Under this body of conceptualisation, a pure public good has two attributes. One is that, unlike a standard private good like a peanut butter sandwich, which can benefit only one consumer (although it can be split and shared), a public good provides atmospheric benefits that all can enjoy. In the language of economists, pure public goods are non-rivalrous in use. Your benefiting from a public good in no way diminishes my ability to so benefit. The second attribute is that, if the good or service is provided at all, there is no way to deny access to any person, or to require direct payment for access. National security is a standard example of a public good. Scientific knowledge often is used as another example. For a neighbourhood, the quality of the access roads has strong public good properties. 
There are several things to note about this conceptualisation. As I have stressed on several occasions, publicness generally is a matter of degree, in both dimensions. A defence force may protect some regions, but not others, and given a resource constraint, defence of one area may be at the expense of another. Thus defence is not completely atmospheric or non-rivalrous in use. On the other hand, if one lives in a protected region, protection cannot be withheld if a person does not pay up, although a person can be placed in gaol for not paying taxes. In contrast, scientific knowledge does seem truly to be non-rivalrous in use; you and I can use the same fact or understanding at the same time. However, the creator of that knowledge may be able to patent it, and to sue us for using it without paying a licence fee.

Laypersons have tended to associate the concept of the public good with the impossibility or undesirability of making those who benefit pay directly for use, and to recognise that adequate provision of goods or services so characterised requires some kind of collective procurement machinery. Sometimes this can be provided through non- governmental organisations, like churches, or community voluntary organisations, which are financed through donations. Thus many suburban neighbourhoods have neighbourhood associations which collectively decide on road maintenance, and collect dues from members. But for large-scale public goods of this type we generally rely on governments.

Generally there is no real alternative. Absent some mechanism for collective decision making, or for collecting taxes, and nothing or next to nothing would be provided. There may be dispute about the magnitude and allocation of public spending, about who should pay, and about how procurement or provision should be arranged, but the principle of governmental determination of the spending on large-scale pure public goods is not in serious dispute.

However, there is a significant collection of goods and services that are non-rivalrous in use, or nearly non-rivalrous, in that the cost of making them available to additional users is very small, but where access can be denied, or users made to pay up before they gain access. I have called this class 'latent public goods'. Prominent on the list of latent public goods I would include those that are or which provide information or knowledge: science, technology, databases, TV signals. To a considerable extent these are marked by nonrivalrousness in use, but access can be barred to those who do not pay a fee. Parks and roads also have the characteristics of latent public goods. Their use is non-rivalrous, at least up to the point where they become crowded. But under appropriate institutional arrangements, for-profit suppliers can make money providing them by requiring their users pay up at a level that covers average cost plus a margin for profit. This is a real option.

For market enthusiasts, this generally is the preferred way of organising and governing these activities. However, while sometimes overlooked in the discussion, there is a downside to governing an activity with latent public good properties in this way, because some users and uses where the good or service has significant value almost surely will be shut out, even though the 
real incremental cost of that use is zero or close to zero. The cost of this exclusion may be, or may be deemed to be, modest, or it may be very large.

On the other hand, collective demand machinery may be put in place as part of the governance mechanism. The decision about how much and what kind to procure may be made publicly, the good or service procured using public funds, and access made free or with nominal use charge. Such a collective demand-side governance mechanism avoids the costs of limiting access to a latent good or service where the real cost of extending service is zero or small. But it does involve the real cost of putting in place and operating collective decision-making machinery, where there may be little agreement, and little objective basis for deciding, how much to provide. There also is the fractious issue of who is to pay the taxes.

I believe that a number of the current arguments about the appropriate roles of markets, and of public funding, involve latent public goods. The funding of basic science is one of the more interesting and important of these issues, and I will consider it in more detail in the next section.

\section{Goods and services that 'ought to be public'}

I return now to the remark I made earlier that many laypersons have a conception of the public good that differs significantly from the technical concept of economists. For many laypersons, public goods are what we fund publicly and make generally available. In cases like defence, this usage squares with the technical concept of public goods used by economists. But in many instances, it does not, at least not immediately. I gave primary and secondary education as an example.

Clearly there is a lot of private benefit for those who are getting an education. Some economists, therefore, have used education as an example of a 'publicly funded private good'. Most economists are comfortable with the notion that education can yield significant positive 'externalities', through enhancing the legitimate earnings' potential of people who otherwise might be tempted to crime, and in the form of the benefits to all of us of a better informed citizenry. This provides an explanation that makes economists comfortable as to why there should be public subsidy of education. But it would appear that few economists are comfortable, at least at first thought, with the notion that education provides a public good, in their technical sense of the term.

However, I want to argue that, if one broadens one's conception of the values involved, education has some strong public good properties. Thus the effects of a better informed citizenry certainly can be regarded as atmospheric. Also, in the eyes of many people a good education available to all is necessary for there to be equality, or near equality, of opportunity in a society, and hence free public education contributes to the fairness of a society. People clearly do care about the characteristics of the society in which they live. And to the extent that they do, education provides an atmospheric public good, at the same time as it provides a private good with externalities. From that same point of view, the quality of the criminal justice system 
can be considered a public good, with equality of access to it a necessary condition for a just society.

Modern societies fund publicly, and provide free or highly subsidised access to a variety of goods and services where extending the use to more persons and uses definitely is costly. Economists, while often strongly sympathetic to the idea of positive public policies to equalise incomes, or at least put a floor under living standards, generally have had considerable difficulty in rationalising the furthering of these objectives by selecting certain goods and services and making them 'publicly' available, in contrast with simply redistributing money income. I am proposing that the focus on particular goods and services makes sense, if certain of them can be particularly associated with the standards of justice in a society or with meeting basic human needs, and which hence should not be rationed by the market.

However, it is not at all clear just how one identifies and limits this class. The arguments for including a right to vote (but remember the old Poll Tax), a right to equality of access to the criminal justice system, to a decent education and to at least a floor level of general living standards are clear enough. So, too, the case for covering the costs of standard medical care for people who cannot afford it, and of assuring the availability of health insurance that covers very costly procedures. But why have many societies opted to remove a payment requirement for even relatively well-to-do people for even relatively low-cost and routine medical services? Should university-level education be on the list?

I believe my conceptualisation here of what the argument is all about is basically correct. But I do not see a clear way of deciding in particular cases; nor, I believe, does anyone else. That is why the debates about removing or weakening market bars to access to services like medical care or day care often are so fractious. Removing a good or service from the realm of governance through customer decisions as to whether or not to spend their own money means not only that public money is required, but that public decisions need to be made regarding who will have access at what terms. I return to this issue in the next section.

The externalities' problem: bringing broader interests to the governing structure The notion of economists externalities is meant to refer to by-products of economic activity that have negative or positive consequences which are not reflected in the prices or other benefits and costs perceived by those who engage in the externalities-generating activity. Environmental contamination is an obvious example of a negative 'externality', and a clear case where there is a value at stake in the operations of an activity, with no one to represent and fight for it, at least in the simple model of market governance put forward in economic textbooks. In a famous article written some time ago, Ronald Coase argued that, if property rights are clear and strong, and the number of interested parties relatively small, markets can in fact deal with such problems. Those who value clean air or water can simply 'buy' behaviour that respects 
those values from the potential polluter. The problem arises when those who care about the values which could be neglected are dispersed. In that case some kind of collective action machinery is needed to bring them in. A good way to think about regulation, or a tax on pollution, is to see these measures as the result of governmental actions that have brought in a broader range of interests to the governing structure of an activity or sector.

But the general problem here is to delineate the range of interests which should be represented, their relative influence and the mechanisms through which they operate to make their values felt. The latter can range from public interest advertising or boycotts, which can proceed without direct access to governmental machinery, to lawsuits which involve general governmental apparatus, to particular pieces of special regulation and associated control machinery. Much of the public controversy is about the latter.

It is conventional in economics to think of the costs of an externality as objective, and in principle at least measurable, and amenable to having a market-based value placed on them. However, in many cases this is not quite the case. The concerns about the 'externality' are held by particular groups, and may be quite subjective. Consider the interests of certain groups in preserving particular species or particular wilderness areas. Or consider regulation or prohibition of the sale of drugs or guns. This can be rationalised as dealing with an externality. However, it is apparent that many people strongly believe that drugs should be prohibited not because they feel particularly threatened by drug-related crime, but because they consider drug use, by anybody, to be wrong. Or reflect on prohibitions on prostitution.

To a large extent, prohibitions on certain activities, which economists might be inclined to rationalise as attempts to deal with externalities, reflect notions on the part of some people and groups regarding what is appropriate activity and what is not. A large part of the argument in this arena is about which values, and whose values, are to count, and through what mechanisms. It is hard to identify an activity, or a sector, where there are not some values at stake that go beyond the direct interests of the customers, and of the suppliers. The question, of course, is where to draw the line.

\section{The issue of uneven expertise and agency}

Economists have become very interested recently in how asymmetric information, in particular differences in the information held by buyer and seller, complicate the workings of markets. I propose that a number of the current controversies about the efficacy of market organisation, about regulation of markets, and about alternatives to market supply, are connected with the asymmetric information problem. In particular, they are associated with difficulties that the user of a service has in assessing the quality and appropriateness of what is provided.

This problem clearly is fundamental in the arena of medical care. In view of the physician's expertise regarding diagnosis and prescription, and the 
obvious dependence of patients on the use of that expertise in their interests, the medical community long has professed that while physicians sell their services on the market they most emphatically do not try to maximise their profits, but rather prescribe in the patients' interests. The credibility of that claim is open to question, but professional ethics clearly can have an influence on behaviour that tends to be neglected in standard models of market governance. To further complicate matters, with the rise of insurance, thirdparty payers found themselves in a position of doubting whether physicians paid enough attention to costs, and worrying about whether physicians, in fact, weren't trying to maximise their own incomes. These multi-interest potential conflicts, in a context where the expertise resides largely with the physician, lies at the heart of several current controversies regarding how to govern the medical care system.

The question of how parents can assess the quality of a child-care centre, and the care their child actually is getting, is a fundamental one in the current controversies regarding regulation of day care. The question of whether parents, and children, can assess educational alternatives effectively, or whether professional teachers and education administrators know best, is a non-trivial one in the current discussion about vouchers. The question of whether forprofit companies will manage prisons effectively and humanely, or whether their interest in profits will lead them to behave in undesirable ways, is central to the controversy about the contracting-out of prison services.

In some cases the issue here shows up in debates about necessary regulation and the mechanisms for regulation enforcement. In other cases the debate is about the proposition that, in circumstances where users cannot make an effective judgement about what they are getting, market organisation, with providers having a strong interest in profits, is an inferior way to govern an activity. There is a tacit, sometimes explicit, presumption that provision by a government agency, or by a not-for-profit organisation, is a better way to go under those circumstances. Of course, whether or not this is so is an open question.

\section{Tension between competition, and co-operation and co-ordination}

Competition is an enormously energising force in many areas of human activity, but not necessarily in all. On the other hand, in some areas of activity co-operation and co-ordination among the actors providing goods and services are extremely important, and competition is undesirable or worse.

Market organisation of supply is well suited to fostering competition. Indeed, there is not much to argue for for-profit unregulated organisation of supply in contexts where competition is not desirable or is unlikely to be sustained (as in the case of natural monopolies). The other side of the coin is that, where considerable competition is desirable, there may be a strong case for opting for market supply. Thus advocates of school vouchers also tend to advocate letting for-profit schools compete for students. Much of the argument for the deregulation of public utilities, and for employing private 
contractors more widely to provide goods and services funded or mandated under government programmes, has been associated with the advocacy of greater competition.

Up to a point at least, market organisation of supply is not incompatible with co-operation and co-ordination among the suppliers regarding certain matters. Thus, in several manufacturing sectors where for-profit firms are the principal suppliers, various co-operative 'pre-competitive' R\&D arrangements have been made. In many industries, firms that otherwise compete have managed to agree to standards of various sorts. It might be noted, however, that government agencies or other government bodies with an interest in or responsibility for the industries in question often have played a key role in organising such co-operation.

In some sectors, like those providing telephone services, or those producing and distributing electricity, the advantages of co-ordination among the different parts of the overall system are very great. Under regimes of regulated private supply, or government ownership of supply, where competition is suppressed or constrained, co-ordination was easy to achieve. Under deregulation, it clearly is a gamble whether rivalrous companies can be induced or forced to co-operate and co-ordinate on vital matters, while remaining competitors. Thus there may be a real tension between allowing local telephone companies to set up competitive long-distance phone services, on the one hand, and requiring them to grant local access to other long-distance services, on the other. Getting managed health-care organisations to share patient information when a customer shifts from one to another has not proved easy.

The question of how to make co-operation and co-ordination on certain matters compatible with competition on others is a tricky one in marketorganised sectors. The need for co-operation and co-ordination, plus the proposition that competition is not needed as part of the governing structure, or is positively harmful, is often used to argue that market organisation and governance are not appropriate in a particular activity or sector.

\section{The problem of potentially coercive power}

American economists are inclined to rationalise the use of antitrust to prevent undue market power from arising, and of regulation to deal with cases where there is natural monopoly, on the grounds that monopolists tend to charge too high a price. It is clear, however, that much of the force behind the policies to break up or rein in monopolies, or regulate them closely, has to do with people's concerns that arise when private bodies gain considerable power over their lives, a matter which may involve but also may transcend being forced to pay monopoly prices. Economists are inclined to rationalise the fact that governments have responsibility for national security and the criminal justice system to the fact that these activities yield 'public goods'. But it probably is at least as relevant that there is near-consensus that it would be highly dangerous to place the power over these activities in private hands. 
These propositions may strike some liberals in the Anglo-American tradition as shocking. The heart of that position has been that strong government is the dominant danger to individual freedoms, and that placing activities under market governance, therefore, serves to increase freedom. The tacit assumptions here, of course, are: first, that concentrations of private power will not in general arise under market governance; and, second, that when they do they are less threatening than government power to individual freedoms. However, I propose that, in many areas, that is just what the debate regarding the appropriate roles of market and non-market elements in the governance of an activity is all about.

Much of the current debate is proceeding in two distinct, if overlapping, arenas. There is, first, the issue of how to govern what used to be called public utilities - activities like the telephone service, electricity generation and distribution, urban water supply, the railroads' system and urban mass transport. As noted, these used to be regarded as 'natural monopolies'. In the United States traditionally they were left in private hands but tightly regulated; in other countries they often were governed as 'public enterprises'. The widespread move towards deregulation and privatisation represented a strong shift in the direction of market governance of these activities. As I noted above, where competition has emerged in these sectors, some non-trivial co-ordination problems have developed as well. And where competition has not proved sustainable, there are serious questions regarding how to control private power.

The other arena involves services for which the government still is responsible and accountable, but which under the movement towards privatisation, increasingly are provided through private contractors. Clearly it is appropriate that the police system should procure uniforms and weapons through the market. The question is whether it is appropriate for the management of activities like prisons to be contracted out, and what kind of controls there should be on private police forces.

\section{Reprise}

Many years ago, F. A. Hayek argued that economic systems are very complex, that effective ones are the result of a time-consuming evolutionary process that selected on institutions that worked, and that humans never could fully comprehend or consciously design an effective economic system. Hayek's observations were meant to warn against trying to build a communist economic system from a theoretical design, and were a forecast that any attempt to do so almost surely would fail. He proved to be correct.

Of course, the referent of Hayek's proposition about the complexity of economic systems was the capitalist system, as it had developed by the early post-Second World War period. Thus, his comments would seem to be as germane to trying to build a capitalist economic system from scratch as they are to trying to build a communist one. And history seems to bear out that proposition (see Hayek 1967, 1973). 
Almost all of the economies that used to profess communism, but recently have attempted to reform towards market capitalism, continue to struggle, and some (Russia, for example) are doing very badly. The original prescription given to them for developing an effective form of market capitalism was a relatively simple one: establish a body of law that respects private property and enables transactions to proceed smoothly; privatise the organisations that produce goods and services, and encourage these new firms to seek out markets and try to make money; establish a financial system that funds companies which have promising prospects for profit making and keeps money out of the hands of others; keep government spending and involvement in the economy more generally low; and adopt macroeconomic policies that avoid inflation. There also was a reminder that government needed to ensure the provision of basic public goods and infrastructure, and to maintain some kind of a safety net for the unfortunate. However, establishing a regime of private firms and markets was assigned first priority. It is apparent that this simple prescription has proved insufficient to guide effective transformation.

Of course, it can be argued that the problem is not so much not knowing what is needed, as not having the will to do what is needed. However, following Hayek's logic, there are good reason to believe that, at their best, the economists' models of how capitalism works can provide only a very rough guide to how to design and build. They can point in the right directions, but getting it right inevitably requires a lot of trial, error, and try-again learning.

Good theories can help if they point broadly in the right directions, and provide useful interpretations for what goes right and what goes wrong. But theories can hinder efforts at reform when they point in the wrong direction, or provide misleading interpretations of the problems that arise in the course of reform. By their nature, theories simplify and abstract. But oversimplification, and abstraction that leaves out essential elements, can be a real problem.

The burden of this essay has been that the standard theory of capitalist economic organisation which today is used to guide policy is much too simplified. By missing the complexity, the variegation and the limits of markets, and the wide variety of non-market mechanisms that mark modern capitalist economies, and enable them to work as well as they do, they often hinder efforts at reform.

Of course, the focus of this essay has not been on building capitalism from scratch, as has been the challenge in the old communist states, but rather on dealing with the new challenges facing advanced and largely successful capitalist economies. A point implicit in the basic argument I have developed, that I now want to make explicit, is this. Economic systems are always evolving. They always are facing new problems, challenges and opportunities, some generated internally (as today's new technologies), some coming from external forces. Thus they always are in the process of trying to reform themselves. This reforming is never ending, but it tends to come in waves. 
Thus the period after the Second World War was one of dramatic reform of capitalist systems, driven by a broadly accepted theory that raw capitalism just was not working, economically or politically, and that there was a need to build a truly mixed economy. A number of commentators argued that the wave of reform overshot. We went through another wave of reform in the 1980s under the theory that a purer and simpler form of capitalism would work much better. We may have overshot here too.

In any case, I think we need a better conceptualisation of what modern capitalist economic organisation is and how it works than today is common currency to guide our reforms in the early twenty-first century. A good part of that understanding, I am arguing, involves an appreciation of the complexities and limits of markets.

\section{References}

Bell, D. (1960), The End of Ideology, Cambridge, MA, Harvard University Press. Blyth, M. (2000), 'Great transformations', Manuscript.

Coase, R. (1960), 'The problem of social cost', Journal of Law and Economics, 3, pp. $1-44$.

Crosland, C. A. R. (1956), The Future of Socialism, London, Jonathan Cape.

Dahl, R. and Lindblom, C. E. (1953), Politics, Economics, and Welfare, New York, Harper.

Fukuyama, F. (1992), The End of History and the Last Man, New York, Avon Books. Hamilton, A. (1791), Report on Manufactures, reprinted in Cooke, J. (1964), The Reports of Alexander Hamilton, New York, Harper Torchbooks.

Hayek, F. (1967), Studies in Philosophy, Politics, and Economics, London, Routledge \& Kegan Paul.

Hayek, F. (1973), Law, Legislation and Liberty, London, Routledge \& Kegan Paul, Vol. 1.

Hegel, G. (1967), Hegel's Philosophy of Right, trans. F. M. Knox, London, Oxford University Press.

Marx, K. (1932), Capital, New York,Modern Library.

Mill, J. S. (1961 [1848]), Principles of Political Economy, New York, Augustus Kelley. Myrdal, G. (1960), Beyond the Welfare State, London, Duckworth.

Owen, R. (1991), A New View of Society and Other Writings, Harmondsworth, Penguin. Plato (1961), The Republic, New York, Pantheon Books.

Polanyi, K. (1944), The Great Transformation, Boston, MA, Beacon Press.

Schonfield, A. (1965), Modern Capitalism, London, Oxford University Press.

Schumpeter, J. (1950), Capitalism, Socialism, and Democracy, New York, Harper.

Smith, A. (1937 [1776]), The Wealth of Nations, New York, Modern Library.

US Government (1960, 1967), Economic Report of the President, Washington, DC, January.

Yergen, D. and Stanislaw, J. (1998), The Commanding Height, New York, Simon \& Schuster. 